Creative commons User License: CC BY-NC-ND

Abstracted by: EBSCOhost, Electronic Journals Service (EJS),

Google Scholar, Directory of Open Access Journals (DOAJ),

Journal Seek, Scientific Commons,

Food and Agricultural Organization (FAO), CABI and Scopus
Journal of Agricultural Extension

Vol. 21 (1) February, 2017

ISSN(e): 24086851; ISSN(Print); 1119944X

http://journal.aesonnigeria.org

http://www.ajol.info/index.php/jae

Email: editorinchief@aesonnigeria.org

\title{
Dietary Intake Adequacy of People Living with HIV/AIDS in Rural Communities of Imo State, Nigeria \\ http://dx.doi.org/10.4314/jae.v21i1.18
}

\author{
Akwiwu Uzoamaka Nwugo \\ Department of Agricultural Economics/Extension and Rural Development. Imo State University, \\ Owerri \\ E-mail: uzoakwiwu@yahoo.co.uk; 08037783241
}

Akinbile Luqman Abiodun

Department of Agricultural Extension and Rural Development. University of Ibadan, Ibadan E-mail: lakinbile@yahoo.com; 08023250454

\begin{abstract}
This study analysed the dietary intake of People Living with HIV/AIDS (PLWHA) in rural communities of Imo State, Nigeria. A simple random sampling technique was used to sample 114 PLWHA from members of two rural support groups with high prevalence of HIV in Imo State using interview schedule. The data were analysed using descriptive statistics, Pearson product moment correlation, and t-test at 0.05. Mean involvement in agriculture was 12.7 and reduced to 7.0 after HIV infection. Extent of involvement in agriculture significantly reduced pre and post HIV infection ( $t=8.1)$. Diet diversity score was low among the majority (62.3\%) of the PLWHA, with a mean of $4.3 \pm 1.6$, and diet adjudged severely inadequate. However, change in level of involvement in agriculture had no significant correlation with dietary intake ( $r=-0.01)$. The study concluded that diet of PLWHA in Imo State was inadequate, thus there is need for extension to collaborate with the health sector to develop nutritional guideline for PLWHA in rural communities.
\end{abstract}

Keywords: People Living with HIV/AIDS, Diet diversity, Dietary intake.

\section{Introduction}

\section{Background to the study}

Agricultural productivity anchors on the factors of production: land, capital, labour and entrepreneur (the farmer). Therefore, land, supply of agricultural inputs, loans, credits and subsidies in agriculture may contribute to achieving optimal productivity, the functionality of these factors, however, rests on the coordination of the entrepreneur, the majority of who are rural dwellers. Such coordination is influenced by their state of health.

The impact of HIV/AIDS on agriculture is enormous: labour shortage, reduction in farm size, substitution of cash crops for crops which require less labour and strength to produce, poor household nutrition, food insecurity, economic losses among others. According to USAID (2001), for every $1 \%$ decrease in the supply of labour, production will decrease by $0.3 \%$. The 
Creative commons User License: CC BY-NC-ND

Abstracted by: EBSCOhost, Electronic Journals Service (EJS),

Google Scholar, Directory of Open Access Journals (DOAJ),

Journal Seek, Scientific Commons,

Food and Agricultural Organization (FAO), CABI and Scopus

\author{
Journal of Agricultural Extension \\ Vol. 21 (1) February, 2017 \\ ISSN(e): 24086851; ISSN(Print); 1119944X \\ http://journal.aesonnigeria.org \\ http://www.ajol.info/index.php/iae \\ Email: editorinchief@aesonnigeria.org
}

World Health Organization also estimated that local losses in agricultural productivity from AIDS at the households or village level range from 10 to $15 \%$ in about ten sub-Saharan African countries, including Nigeria. Therefore, HIV goes beyond being a health issue as it has become more of a social and economic issue.

There have been several interventions at local government and state level in Nigeria by various stakeholders such as federal government, donor agencies, NGOs and others to obviate and arrest the scourge of HIV/AIDS through provision of Anti-Retroviral Drugs, clinical care and support, yet, the prevalence rate remains high and death toll from HIV/AIDS escalates at an alarming rate particularly in the rural areas. According to UNAIDS (2015), approximately 3.5 million people are living with HIV/AIDS with an estimate of 2.9 million who do not have access to Anti Retroviral Therapy (ART). In 2014, out of 1.5 million PLWHA who were eligible for ART, only 747,382 were enrolled. At the end of 2015, approximately 250,000 new infections occurred and an estimate of 180,000 AIDS related death was reported. Unfortunately, HIV infection occurs mostly among those in the sexually active age, ranging from 15-49 years, as the most common means of transmission in Nigeria is heterosexual. (FMH, 2010). Those who fall within this age range are considered the most active, vibrant and most productive within any given community.

The statistics above indicates that urgent attention needs to be paid to support PLWHA and arrest the high rate of mortality among carriers of the virus. To achieve this, various studies (Castleman et al (2004) and FANTA (2004)) have shown that adequate dietary intake along side ART is the key. This is because adequate dietary intake helps keep the immune system strong, enabling one to better fight the disease and help the body of PLWHA process the many medications taken (Nanziri,2008). HIV/AIDS attacks the immune system making the body susceptible to opportunistic infections like fever, diarrhoea, tuberculosis, pneumonia, sores and blisters and has no cure. Therefore, efforts made by government and other concerned organisations must be augmented by the infected individual through proper and adequate dietary intake. This may help to delay rapid progression from HIV to AIDS and reduce high mortality as a result of HIV/AIDS. Poor nutritional intake for PLWHA inadequate dietary intake has dire consequences for an already compromised immune system. 
Creative commons User License: CC BY-NC-ND

Abstracted by: EBSCOhost, Electronic Journals Service (EJS),

Google Scholar, Directory of Open Access Journals (DOAJ),

Journal Seek, Scientific Commons,

Food and Agricultural Organization (FAO), CABI and Scopus

\author{
Journal of Agricultural Extension \\ Vol. 21 (1) February, 2017 \\ ISSN(e): 24086851; ISSN(Print); 1119944X \\ http://journal.aesonnigeria.org \\ http://www.ajol.info/index.php/iae \\ Email: editorinchief@aesonnigeria.org
}

According to World Bank (2007), adequate dietary intake cannot cure HIV infection, but it is a panacea to maintain the immune system, prevent opportunistic infections, sustain physical activity and achieve optimal quality of life. In this way, infected people can live longer and more meaningful life despite the virus. However, Nanziri (2008) noted that the role played by good nutrition and adequate dietary intake as a major component of managing the health of PLWHA is poorly emphasised in most HIV interventions.

The understanding and practice of adequate dietary intake among PLWHA is, therefore, an important step in the direction towards reducing the mortality rate from the pandemic and the consequent effect on agriculture and national economy as a whole. It is against this background that this study seeks to provide answers to the following research questions:

1. What are the respondents' personal characteristics?

2. What are the respondents' levels of change in involvement in agriculture?

3. What is the level of adequacy of respondents' dietary intake?

\section{Research objectives}

The general objective of the study was to analyse the dietary intake of people living with HIV/AIDS in rural communities of Imo State, Nigeria.

\section{Specific objectives}

The specific objectives of the study were to:

1. describe the personal characteristics of PLWHA in rural communities of Imo States;

2. examine change in level of involvement in agricultural activities among respondents;

3. access the respondents' level of adequacy of dietary intake.

\section{Research hypothesis}

$\mathrm{H}_{0} 1$ There is no significant relationship between respondents' change in level of involvement and the level of adequacy of their dietary intake.

\section{Methodology}

The study area was Imo State. The state is located between longitude $6^{0} .36^{1}$ and $7^{0} .28^{1}$ East and latitude $5^{0} .57^{1}$ and $5^{0} .11^{1}$ North. The state is administratively divided into three agricultural zones namely Okigwe, Orlu and Owerri and each zone has a government owned hospital were Anti Retroviral Therapy are administered to PLWHA. The state has a total population of $3,927,563$ (NPC, 2006). The major economic activity of the people is 
Creative commons User License: CC BY-NC-ND

Abstracted by: EBSCOhost, Electronic Journals Service (EJS),

Google Scholar, Directory of Open Access Journals (DOAJ),

Journal Seek, Scientific Commons,

Food and Agricultural Organization (FAO), CABI and Scopus

\author{
Journal of Agricultural Extension \\ Vol. 21 (1) February, 2017 \\ ISSN(e): 24086851; ISSN(Print); 1119944X \\ http://journal.aesonnigeria.org \\ http://www.ajol.info/index.php/iae \\ Email: editorinchief@aesonnigeria.org
}

agricultural production. Crop production and animal husbandry are practiced. The major crops are cassava, yam, maize, banana, plantain, pineapple, oil palm, melon and other vegetables. The major animals reared include goats, sheep, pigs, cattle and poultry.

A multi stage sampling procedure was used to sample respondents for this study. The first stage was to purposively select two LGAs (Aboh Mbaise and Ahiazu Mbaise LGAs) to capture rural communities with high HIV prevalence in Imo State (FMH, 2014). In stage two, all HIV/AIDS support groups within the two LGAs were sampled comprising of one support group each in Aboh Mbaise and Ahiazu Mbaise of Imo State. Members of the support group are those who have tested and found to be infected with HIV. In stage three, list of all registered members of PLWHA in the support groups were obtained from the groups. Fifty percent of registered members in each group were sampled using simple random sampling technique. A total of 129 respondents were sampled for the study. Rate of return of questionnaire however was $88.38 \%$. Therefore, only 114 questionnaires were returned and were reported in this study. Interview schedule was used to collect quantitative data for the study.

Respondents' level of involvement in agricultural activities were categorized into pre-planting operations, planting operations, post planting operations, marketing of produce, processing of produce, animal husbandry and fishery. The level of involvement pre HIV infection and post HIV infection were measured using a three point scale of (a) Often (b) Occasionally (c) Never

Often was scored two, Occasionally, one and Never, zero and the mean computed. Based on the mean Pre HIV infection (12.7) and Post HIV infection (7.0) respondents were categorized into low and high level of involvement in agriculture; Pre HIV infection low (0-13), High (14-34), Post HIV infection low (0-7), High (8-30)

Level of adequacy of dietary intake data were collected from respondents using the Individual Dietary Diversity Score adapted from FANTA scale (2007). Respondents were asked to tick Yes or No to the consumption of any of the options of 12 food groups given which are: carbohydrates, tubers, dark green leafy vegetables, fruits, meat, eggs, sea foods, 
Creative commons User License: CC BY-NC-ND

Abstracted by: EBSCOhost, Electronic Journals Service (EJS),

Google Scholar, Directory of Open Access Journals (DOAJ),

Journal Seek, Scientific Commons,

Food and Agricultural Organization (FAO), CABI and Scopus

\author{
Journal of Agricultural Extension \\ Vol. 21 (1) February, 2017 \\ ISSN(e): 24086851; ISSN(Print); 1119944X \\ http://journal.aesonnigeria.org \\ http://www.ajol.info/index.php/iae \\ Email: editorinchief@aesonnigeria.org
}

food made from beans, yoghurt, milk or milk products, food made from oil, fat or butter, sugar or honey and beverages (alcoholic and non-alcoholic), using a 24 hours diet recall method. A 'yes' response was scored one and a 'no' response zero. The highest score was 12 while the lowest score was 0 . The higher the score, the more diversified the diet and the more adequate. The scores were grouped into terciles (Ruel, 2003) as Low (0-4) (severely inadequate), average (5-8) (inadequate) and high (9-12) adequate dietary intake. Adequacy of respondents' dietary intake was judged based on their position on the scale.

Descriptive and inferential statistics were used to analyze the data. Descriptive statistics used include; mean, frequency and percentage distribution while inferential statistics used were Pearson Product Moment Correlation and t-test.

\section{Result and Discussion}

Age

Age distribution of respondents as presented on Table 1 shows that in Imo, 30.7\% were within the age range of $31-40$ years with a mean age of $41.3 \pm 11.5$ years. This suggests that the majority of the respondents were in their economically active and productive years. This is in agreement with Kormawa (2005) who opined that HIV/AIDS affects the most active and productive segment of the rural society. The prevalence of HIV/AIDS within this age group is an indication that agricultural productivity and inevitably food security may be threatened, thereby putting families increasingly at risk of food unavailability and poor nutritional intake in the study area.

\section{Sex}

More females (65.8\%) than males were infected with HIV. This is in agreement with FMH (2014) report which states that HIV/AIDS prevalence rate were generally higher among females than males. In Africa, Nigeria inclusive, $70 \%$ of agricultural production come from small farmers who are largely rural women Kormawa (2005). This is a dangerous trend as the majority of women with HIV/AIDS implies threat to food security and poor nutritional intake by families. 
Creative commons User License: CC BY-NC-ND

Abstracted by: EBSCOhost, Electronic Journals Service (EJS),

Google Scholar, Directory of Open Access Journals (DOAJ),

Journal Seek, Scientific Commons,

Food and Agricultural Organization (FAO), CABI and Scopus

\author{
Journal of Agricultural Extension \\ Vol. 21 (1) February, 2017 \\ ISSN(e): 24086851; ISSN(Print); 1119944X \\ http://journal.aesonnigeria.org \\ http://www.ajol.info/index.php/iae \\ Email: editorinchief@aesonnigeria.org
}

\section{Marital status}

The majority $(35.1 \%)$ of the respondents were single and only $25.4 \%$ were married. The finding is in tandem with that of Ofonime (2012) who found that singles were more infected than married people in a study conducted on PLWHA in Cross Rivers State. HIV infection within a family distorts family structure, reduces quality and quantity of agricultural labour. As a result of this, food production may reduce and food security becomes threatened.

\section{Household size}

The majority (47.4\%) had a household size of 5-8 with mean of 6.0 \pm 3.2 members. Similarly, the findings of Adebayo (2012) indicated average household size for most families to be between 5-8 members. The household is fairly large which may result in reduced food availability, reduced food intake and poor nutritional status.

\section{Educational status}

The highest educational level attained by most (40.4\%) of the respondents was secondary school education. This is consistent with the findings of Mofolorusho, Fatiregun and Osagbemi (2013) that most rural dwellers have at least a secondary school education. Education plays a major role in information communication as it is necessary for proper processing of information as observed by Oladeji and Oyesola (2000). Therefore, knowledge on dietary intake is expected to be high, resulting in a positive attitude towards adequate dietary intake. 
Creative commons User License: CC BY-NC-ND

Abstracted by: EBSCOhost, Electronic Journals Service (EJS),

Google Scholar, Directory of Open Access Journals (DOAJ),

Journal Seek, Scientific Commons,

Food and Agricultural Organization (FAO), CABI and Scopus

\author{
Journal of Agricultural Extension \\ Vol. 21 (1) February, 2017 \\ ISSN(e): 24086851; ISSN(Print); 1119944X \\ http://journal.aesonnigeria.org \\ http://www.ajol.info/index.php/iae \\ Email: editorinchief@aesonnigeria.org
}

Table 1: Percentage distribution of respondents according to personal characteristics

\begin{tabular}{lll}
\hline Variable & $\%$ & Mean \pm SD \\
\hline Age (years) & 2.6 & \\
$\leq 20$ & 18.4 & \\
$21-30$ & 30.7 & \\
$31-40$ & 25.4 & $41.2 \pm 11.5$ \\
$41-50$ & 17.5 & \\
$51-60$ & 5.3 & \\
$61-70$ & & \\
Sex & 65.8 & \\
Female & 34.2 \\
Male & \\
Marital status & 35.1 & \\
Single & 25.4 \\
Married & 6.1 \\
Divorced & 33.3 \\
Widowed & \\
Household size & 38.6 \\
1-4 & 47.4 \\
5-8 & 10.5 \\
9-12 & 3.5 \\
Educational attainment & \\
Non formal education & 3.5 \\
No formal education & 6.1 \\
Primary education & 26.3 \\
Secondary education & 40.4 \\
Tertiary education & 23.7 \\
& \\
\end{tabular}

\section{Involvement in Agricultural Activities Pre and Post HIV Infection}

Table 2 shows the respondents' level of involvement in agriculture before having the knowledge of being HIV infected and their level of involvement now that they live with the virus. Mean involvement of respondents in agricultural activities before being aware of HIV infection was; land clearing 1.04, removing stumps 0.96, planting on the field 1.02 and harvesting of crops 1.03. Currently while living with HIV, only 0.52 cleared their land, 0.46 removed stumps, 0.66 planted on the field and 0.61 harvest their crops. This is similar to the findings of Kormawa (2005) who in a survey conducted on the Zimbabwe Farmers' Union, found that agricultural output declined by nearly 50 percent in the households affected with 
Creative commons User License: CC BY-NC-ND

Abstracted by: EBSCOhost, Electronic Journals Service (EJS),

Google Scholar, Directory of Open Access Journals (DOAJ),

Journal Seek, Scientific Commons,

Food and Agricultural Organization (FAO), CABI and Scopus

\author{
Journal of Agricultural Extension \\ Vol. 21 (1) February, 2017 \\ ISSN(e): 24086851; ISSN(Print); 1119944X \\ http://journal.aesonnigeria.org \\ http://www.ajol.info/index.php/iae \\ Email: editorinchief@aesonnigeria.org
}

AIDS. If left unchecked, the impact of HIV/AIDS on agriculture would be full blown where coping mechanisms are likely to fail and food security severely threatened.

From the results, it was also observed that the majority of the respondents engaged in crop farming alone. Only a few explored other forms of agriculture such as animal breeding before (0.10) and now (0.01). Mean involvement in fishery was 0.00 before HIV and 0.00 now. It is important that extension workers help explore these other aspects of agriculture (animal rearing and fish farming) which are less laborious than crop farming and can also supply households with PLWHA the much needed protein for body building.

Table 2: Mean level of involvement in agricultural activities pre and post HIV infection

\begin{tabular}{lll}
\hline Variable & Pre infection & Post infection \\
\hline Land clearing & & \\
Burning of cleared land & 1.04 & 0.52 \\
Parking of unburnt materials & 1.05 & 0.53 \\
Stumping & 1.03 & 0.52 \\
Seed selection & 0.96 & 0.46 \\
Planting in the field & 1.04 & 0.64 \\
Weeding & 1.02 & 0.66 \\
Thinning & 1.04 & 0.59 \\
Staking & 1.00 & 0.59 \\
Fertilizer application & 1.01 & 0.54 \\
Harvesting & 1.03 & 0.63 \\
Storage & 1.03 & 0.61 \\
Marketing of crop produce & 1.01 & 0.59 \\
Processing of crop produce & 0.05 & 0.04 \\
Breeding & 0.04 & 0.04 \\
Feeding animals & 0.10 & 0.01 \\
Marketing of animal produce & 0.10 & 0.04 \\
Processing of animal produce & 0.05 & 0.04 \\
Stocking of fish & 0.05 & 0.03 \\
Feeding & 0.00 & 0.02 \\
Marketing of fish produce & 0.00 & 0.00 \\
Harvesting of fish & 0.00 & 0.00 \\
Processing of fish & 0.01 & 0.00 \\
& 0.00 & 0.00 \\
\hline
\end{tabular}

\section{Categorization of Respondents' Level of Involvement in Agricultural Activities Pre and}

\section{Post HIV Infection}

Table 3 reveals that, $46.5 \%$ of the respondents had high level of involvement in agricultural activities as against $53.5 \%$ who had low level of involvement in agricultural activities before they were infected. After being HIV positive, 41.2\% had high level of involvement in 
Creative commons User License: CC BY-NC-ND

Abstracted by: EBSCOhost, Electronic Journals Service (EJS),

Google Scholar, Directory of Open Access Journals (DOAJ),

Journal Seek, Scientific Commons,

Food and Agricultural Organization (FAO), CABI and Scopus

\author{
Journal of Agricultural Extension \\ Vol. 21 (1) February, 2017 \\ ISSN(e): 24086851; ISSN(Print); 1119944X \\ http://journal.aesonnigeria.org \\ http://www.ajol.info/index.php/jae \\ Email: editorinchief@aesonnigeria.org
}

agricultural activities as against $58.8 \%$ that had low level of involvement in agricultural activities .

Thus many of the respondents were still actively involved in agricultural activities, even with their HIV status. Although it may not prevent involvement in agriculture, it may cause loss of man days, reduce their productivity and quality of farm produce. Therefore, with proper management using ART and adequate dietary intake, PLWHA can live normal lives for a long period of time (World Bank, 2007).

Table 3: Categorization of respondents' level of involvement in agriculture pre and post HIV infection

\begin{tabular}{llll}
\hline Scores & Pre HIV infection & Scores & Post HIV infection \\
\hline & $\%$ & & $\%$ \\
Low & 53.5 & Low & 58.8 \\
High & 46.5 & High & 41.2 \\
Mean \pm SD & $12.7 \pm 11.1$ & Mean \pm SD & $7.0 \pm 8.0$ \\
\hline
\end{tabular}

Difference in Mean Level of Involvement of Agricultural Activities Pre and Post HIV Infection

A significant $(\mathrm{p} \leq 0.05)$ difference was observed in involvement of agricultural activities pre $(\bar{x}=12.7)$ and post $(\bar{x}=7.0)$ HIV infection by respondents. This implies that food production and availability would be affected particularly at household level and this may cause a lowering of the body immune system due to inadequate dietary intake (Ekele, 2003). AIDS prolongs and deepens poverty, making it harder to escape this inevitable outcome if not properly managed.

Table 4: Difference in involvement of agricultural activities pre and post HIV infection

\begin{tabular}{lllll}
\hline Variable & Mean & Std.Deviation & Mean diff. & t-value \\
\hline Pre & 12.7 & 11.1 & 5.7 & $8.1^{*}$ \\
Post & 7.0 & 8.0 & & \\
\hline \multicolumn{1}{c}{$\mathrm{P} \leq 0.05$} & & & &
\end{tabular}


Creative commons User License: CC BY-NC-ND

Abstracted by: EBSCOhost, Electronic Journals Service (EJS),

Google Scholar, Directory of Open Access Journals (DOAJ),

Journal Seek, Scientific Commons,

Food and Agricultural Organization (FAO), CABI and Scopus

\author{
Journal of Agricultural Extension \\ Vol. 21 (1) February, 2017 \\ ISSN(e): 24086851; ISSN(Print); 1119944X \\ http://journal.aesonnigeria.org \\ http://www.ajol.info/index.php/iae \\ Email: editorinchief@aesonnigeria.org
}

\section{Respondents' Dietary Intake Using 24 hours' Diet Recall}

The distribution of respondents' 24 hours diet recall as presented on Table 6 reveal that the majority $(78.9 \%)$ of the respondents ate cereals, $64.9 \%$ ate tubers while dark green leafy vegetables and food made from beans were consumed by $55.3 \%$ and $47.4 \%$ of the respondents respectively. Food groups least consumed were food made from yoghurt, milk and milk products $(11.4 \%)$ and eggs (7.9\%). This result is consistent with the report of Sanusi (2010) on food group consumption pattern in Nigeria which reveals that consumption of cereals and tubers where consumed by a high percentage of people, while the consumption of milk and milk products and eggs were consumed by a few. Diets that are predominantly starchy staples are usually low in micronutrients which is needed to strengthen the body immune system.

This situation presents the urgent need for extension agents and stakeholders to promote the cultivation and consumption of food that give essential nutrients (fruits and vegetables) required for optimal health and the practice of animal husbandry in order to provide protein from animal sources. Apart from the high nutritive value of vegetables, they can also serve as means of providing additional income for households who produce them (Abugu et al, 2013).

Table 6: Percentage distribution of respondents based on 24 hours' diet recall dietary intake

\begin{tabular}{ll}
\hline Food group & $\%$ \\
\hline Cereals (millet, wheat, sorghum, maize, bread, others) & 78.9 \\
Tubers (potatoes, yam, cassava, cocoyams, others) & 64.9 \\
Dark green leafy vegetables (Ugu, green leaf, waterleaf, bitter leaf, okro, others) & 55.3 \\
Fruits (mangoes, oranges, paw-paw, guava, others) & 14.9 \\
Meat (beef, pork, rabbit, chicken, offal, others & 49.1 \\
Egg & 7.9 \\
Sea foods (Fresh or dried fish, cray fish, shell fish) & 32.5 \\
Any food from beans & 47.4 \\
Any food from yoghurt, milk, other milk products & 11.4 \\
Any from made with oil. fat or butter & 4.4 \\
Sugar or honey & 13.2 \\
Tea, coffee, cocoa, herbal drink & 42.1
\end{tabular}


Creative commons User License: CC BY-NC-ND

Abstracted by: EBSCOhost, Electronic Journals Service (EJS),

Google Scholar, Directory of Open Access Journals (DOAJ),

Journal Seek, Scientific Commons,

Food and Agricultural Organization (FAO), CABI and Scopus

\author{
Journal of Agricultural Extension \\ Vol. 21 (1) February, 2017 \\ ISSN(e): 24086851; ISSN(Print); 1119944X \\ http://journal.aesonnigeria.org \\ http://www.ajol.info/index.php/iae \\ Email: editorinchief@aesonnigeria.org
}

\section{Categorization of Respondents by Dietary Diversity Score}

Dietary diversity measured by the number of food groups consumed has been shown to be a potential proxy indicator of adequacy of nutrients ( Torheim et al,2004).

The Individual Diet Diversity Score (IDDS) of the respondents as indicated on Table 7 shows that the majority (62.3\%) of the respondents had low IDDS of food group category, while only $2.6 \%$ of the respondents had high IDDS of food group category. The mean score was 4.3 for 12 food groups. This is an indication that respondents' food intake is grossly inadequate. According to Kant (1996), increasing the variety of food and food groups in the diet helps to ensure adequate intake of essential nutrients, and promotes good health. The quality of diets has been shown to be directly related to diversified diet.

Although food intake among people who reside in rural areas is culturally influenced as opined by Wahlquist (2005), this result negates the researcher's submission that it is associated with a more diversified diet. The need to ensure that PLWHA have better access to good nutrition and knowledge of adequate dietary intake becomes apparent

Table 7: Dietary diversity score

\begin{tabular}{lll}
\hline IDDS & $\%$ & Mean \pm SD \\
\hline Low & 62.3 & \\
Average & 35.1 & $4.3 \pm 1.6$ \\
High & 2.6 & \\
\hline
\end{tabular}

There is no significant relationship between change in level of involvement in agriculture and dietary intake adequacy of PLWHA in Imo State.

No significant correlation exists $(r=-0.01 ; \mathrm{p}>0.05)$ between change in level of involvement in agriculture and dietary intake adequacy. This is probably because the majority of the respondents were still actively involved in agricultural activities despite HIV infection while some may be receiving support from other sources aside agriculture. See Table 3

\section{Conclusion and Recommendation}

The dietary intake of most of people living with HIV/AIDS in rural communities of Imo State accessed through the 24 hour diet recall and Diet Diversity Score (IDDS) based on 12 food 
Creative commons User License: CC BY-NC-ND

Abstracted by: EBSCOhost, Electronic Journals Service (EJS),

Google Scholar, Directory of Open Access Journals (DOAJ),

Journal Seek, Scientific Commons,

Food and Agricultural Organization (FAO), CABI and Scopus

\author{
Journal of Agricultural Extension \\ Vol. 21 (1) February, 2017 \\ ISSN(e): 24086851; ISSN(Print); 1119944X \\ http://journal.aesonnigeria.org \\ http://www.ajol.info/index.php/iae \\ Email: editorinchief@aesonnigeria.org
}

groups was low and severely inadequate. It is of paramount importance that extension agents develop nutritional guidelines for PLWHA using local foods, while trying to work out means of livelihood diversification rather than over dependence on crop farming to feed and generate income.

\section{References}

Abugu, R.O., Chah, J.M., Nwobodo C., Asadu, A.N., and Igbokwe E.M. (2013). Agricultural Extension Needs of Farmers in Telfairia Production and Marketing in Enugu State, Nigeria; Journal of Agricultural Extension Vol. 17(1) June, 2013.

Adebayo, O. O. (2012). Effects of family size on household food security in Osun State Nigeria; Asian Journal of Agriculture and Rural Development. 2 (2) 2: 136-141.

Castleman, T.E., Seumo-Fosso and B. Cog. (2004). Food and Nutrition Implications of Antiretroviral Therapy in Resource Limited Settings. FANTA Technical Note No. 7 Washington D.C. Academy For Educational Development, p 25

Ekele, A.M. (2003). Comparative Analysis of Women Farmers Productivity in HIV/AIDS Prevalent and non-prevalent areas of Benue State. An unpublished M.Sc. Thesis University of Ibadan, June, 2003.

FANTA (Food and Nutritional Technical Assistance) Project (2004). 2004 HIV/AIDS. A guide for nutritional care and support. $2^{\text {nd }}$ edition. Washington D.C: Academy for Educational Development.

Federal Ministry of Health (FMH) (2010). National HIV/AIDS Strategic Plan 2010-2015. Abuja Nigeria: Nigeria National Agency for the Control of AIDS, 2010

Federal Ministry of Health (FMH) (2014). National HIV/Syphilis Sero-prevalence Sentinel Survey among pregnant women attending antenatal clinics in Nigeria. Abuja: National AIDS/STI Control Programme. 1-5.

Kant, A. (1996). Indexes of overall diet quality: A Review. Journal of American Dietetic Association 96: 785-91.

Kormawa, J.A. (2005). Impact of HIV/AIDS on African agriculture and role of the consultative group on Agricultural Research. Retrieved November 23, 2010 from www.warda.org/swiha/Dublin paper pdf 13p.

Mofolorunsho K. G., Fatiregun A. A. and Osagbemi K. G. (2013). Socio economic factors influencing the quality of life of people living with HIV/AIDS in Kogi State, Nigeria, International Journal of Tropical Medicine 8 (1): 6-10, 2013.

Nanziri, C. (2008). Factors Associated with Dietary Intake among HIV Positive Adults (18-65 years) at the Mildmay Center, Kampala, Uganda. Dissertation for Master of Public health. Makerere University. Uganda.

National Agency for the Control of AIDS NACA (2012). Global AIDS response country progress Report, Agj. Nig. 2012. 
Creative commons User License: CC BY-NC-ND

Abstracted by: EBSCOhost, Electronic Journals Service (EJS),

Google Scholar, Directory of Open Access Journals (DOAJ),

Journal Seek, Scientific Commons,

Food and Agricultural Organization (FAO), CABI and Scopus

\author{
Journal of Agricultural Extension \\ Vol. 21 (1) February, 2017 \\ ISSN(e): 24086851; ISSN(Print); 1119944X \\ http://journal.aesonnigeria.org \\ http://www.ajol.info/index.php/iae \\ Email: editorinchief@aesonnigeria.org
}

National Population Commission (2006). National population census figures. NPC Bulletin 4: 12.

Ofonime E. J. (2012). Social impact of HIV/AIDS on clients attending teaching hospital in Southern Nigeria SAHARA -J: Journal of Social Aspect of HIV/AIDS: 9(2): 47-53.

Oladeji; J. O. and Oyesola, B. O. (2000). Information needs of rice farmers on harvesting and processing activities is Obafemi Owode Local Government Area of Osun State proceedings of the $6^{\text {th }}$ Annual Conference of Agricultural Extension Society of Nigeria (AESON), Ilorin T. A. Olowu Ed. 144-150.

Sanusi R.A. (2010). An assessment of dietary diversity in six Nigerian states. Afr. J.Biomed Res 13 (3). P161-167

Styen N. P. Neljh, Nantel G. Kenedy G, Labadarios D. (2006). Food variety and dietary Diversity scores in Children; Are the good indicators of dietary adequacy: Public Health Nutrition 9 (5): 644-50.

Torheim L.E, Ouattara F, Diarra M, Thiam F.D, Barikno I, Hatloy A. (2004). Nutrient adequacy and dietary diversity in rural Mali. Eur J Clin Nutr. 2004; 58: 594.604

UNAIDS (2012). Report on global aids epidemic. Retrieved March 13, 2014 from http://www.avert.org

United States Department of Agriculture. (2001). Issues in Food Security'. Agriculture Information Bulletin November 765-9.

Wahlqvist J. (2005). Diversification in indigenous and ethnic food culture. Forum Nutr. (57):52-61

World Bank (2007). HIV/AIDS Nutrition and food security. What we can do. The International Bank for Reconstruction and Development. www.worldbank.org accessed $14^{\text {th }}$ April, 2010. 